Article

\title{
Do Stakeholders Modulate Philanthropic Strategy? Corporate Philanthropy as Stakeholders' Engagement
}

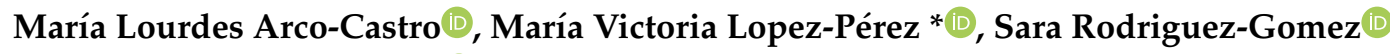 \\ and Raquel Garde-Sánchez $\mathbb{D}$
}

Department of Accounting and Finance, University of Granada, 18071 Granada, Spain; mlarco@ugr.es (M.L.A.-C.); sara@ugr.es (S.R.-G.); rgarde@ugr.es (R.G.-S.)

* Correspondence: mvlopez@ugr.es

Received: 6 August 2020; Accepted: 1 September 2020; Published: 4 September 2020

check for updates

\begin{abstract}
Corporate philanthropy, as an expression of commitment to the common good, can contribute to the creation of social value in companies. This corporate philanthropy can be managed in various ways. The choice of how to channel corporate philanthropy could be, in accordance with stakeholder theory, the result of companies' interactions with key stakeholders and, in accordance with the theory of signaling, a signal that companies use to respond to their demands. This approach contributes to the literature on bottom-up initiatives (stakeholder-managers) as opposed to top-down strategies (board-stakeholders) in relation to corporate social responsibility, which is becoming increasingly important in a society where networks of communication, cooperation and interaction are established. To this end, a study was conducted on 221 European companies indexed in the Dow Jones Sustainability Indices in the year 2018. The findings have several practical implications: The management of corporate philanthropy should take into account the stakeholders' requirements, and stakeholders show greater affinity and trust with the company when philanthropy is channeled through foundations. By contrast, donations are not associated with stakeholder attitudes. As a theoretical implication, this paper supports the theories of stakeholders and signaling by explaining the role of philanthropy in the relationship with stakeholders.
\end{abstract}

Keywords: corporate philanthropy; signaling theory; foundations; donations; stakeholders

\section{Introduction}

Companies' philanthropy is included under the domain of corporate social responsibility (CSR) [1,2]. Specifically, corporate philanthropy includes those actions aimed at the community [3-5] to meet social assistance needs related to education, the arts, culture, medicine or science, or humanitarian attention to natural disasters, among other initiatives [6-8].

Corporate philanthropy refers to the company's strategy towards the community and includes the company's direct actions and activities related to society. These actions can be analyzed as a business strategy [9] that must be managed, and companies must decide how to channel them and to whom they are directed. Corporate philanthropy can create shared value, i.e., generate social value [10], through improved well-being in the community and greater employee satisfaction by generating improved intellectual and relational capital. In addition, given the relationship of interdependence between business and society from the perspective of the economy of the common good, it is proposed to develop a business model that not only seeks economic value but also considers the dimensions contained in the triple bottom line and the balance between them [11]. This will make it possible for companies to survive in the long term and be sustainable, and will favor the common good and cooperation [12]. From this perspective, corporate philanthropy should not be seen as a set of resources allocated to the community but rather as part of business performance that goes beyond the 
economic and takes into account the general interest and demands of different stakeholders as the theory of stakeholders defends $[1,5]$. Thus, this not only expresses interest in meeting the demands of the community, but also acts as a tool that can be managed by the company, taking into account the reactions of its main stakeholders. In this sense, entities would manage corporate philanthropy in such a way that it not only meets the requirements of the stakeholder directly affected by these actions-the community-but also improves relations with the different stakeholders. From the latter perspective, corporate philanthropy, traditionally included in the external dimension of CSR because it is community-oriented, would influence the internal social performance of the company by involving stakeholders such as employees and shareholders [13]. The idea that we propose is that the company, through its corporate philanthropy, not only responds to its commitments to the community but also considers how it affects the rest of its relationships with the main agents with whom it interacts. In this sense, this behavior is not, strictly speaking, a top-down strategy, but rather that it is critical to manage the bottom-up initiatives of the stakeholders. In this way, corporate philanthropy is geared to solving social needs while improving relationships with key stakeholders to ensure better business financial and non-financial performance [14], and corporate sustainability [12].

Considered from this strategic point of view, corporate philanthropy can be managed by companies in various ways. It can be articulated through top-down strategies through discretionary giving, according to management preferences [15] or through bottom-up strategies, by managing the demands of stakeholders [16] or by considering the effect that companies' actions have on them $[17,18]$.

The latter option means that corporate philanthropy can be used as a signal, adjusting management to the demands and initiatives of stakeholders. This last possibility has been little addressed in the literature [19], and yet it constitutes a relevant analysis to be taken into account in the use of philanthropy as a strategic tool. Entities must communicate their corporate strategy adequately, trying to be understood by and generate trust in the stakeholders, and in some way, respond to their initiatives. In this sense, corporate philanthropy is an effect of the company's relations with its stakeholders. The paper argues that, for the corporate philanthropy strategy to have an effect on the company as a whole, it is necessary to complement the top-down strategy with bottom-up initiatives, i.e., to take into consideration the perceptions and attitudes of the firm's stakeholders.

Corporate philanthropy can be articulated through ad hoc or planned actions. When the actions are planned, they are integrated into the core business [20] and form one of its business strategies [21], and can thus be perceived by stakeholders. In this context, how philanthropy is managed may depend on how the company understands that this philanthropy enables stakeholders to trust and identify with the firm.

Corporate philanthropy is usually managed through direct donations or channeled through foundations [22]. Subsequently, companies disclose the actions they have taken in their CSR reports. Direct-resource contributions may be linked to management preferences $[15,23,24]$, in which case, they may be perceived by stakeholders as unplanned or even unreliable. In this case, donations could be perceived as marketing tools to improve the company's image $[25,26]$ or considered to be used to minimize the effects of negligence or controversial actions on the company's reputation [27]. In any case, they may be actions undertaken in a reactive manner with the aim of obtaining short-term benefits and/or meeting the preferences of management.

Through the use of foundations, social actions could be perceived as well-planned and integrated into the company's strategy $[3,28]$. The reasons for this are that, among other things, foundations enjoy greater independence from their parent companies, have autonomy in their decisions and have a financial endowment that protects them from the fluctuations of the business cycle $[29,30]$. The separation between companies and foundations decreases its company managers' discretion, possible influences and personal preferences, and ensures professionalism and coherence with the company's overall strategy [28], which provides greater reliability in the management of resources dedicated to social issues. On the other hand, foundations have a greater capacity to address social needs by supporting causes that are in the best interests of the main stakeholders. In addition, 
they imply a long-term social commitment by mobilizing different resources, not only monetary, and different entrepreneurial capacities, which ensures that the practices are more innovative, active, entrepreneurial and effective [23,31]. The above means that corporate foundations assume a social performance with a long-term time horizon, less influenced by management and more proactive towards the interests and social trends of different groups.

In this sense, foundations could act as signals to business stakeholders. Thus, according to the theory of signaling, the choice of foundations to manage actions with the community would be a signal issued by the company to improve the perception and assessment of the main stakeholders of the company [32]: employees, customers, investors, and the community [13].

The objective of this work is, first of all, to illustrate that the exercise of corporate philanthropy is developed by considering the optimal reception by stakeholders. In this sense, this paper contributes the theory of signaling in the field of CSR. Secondly, unlike most studies, which jointly analyze ad hoc donations and foundations, this paper considers them separately, observing that the reasons that lead companies to manage their philanthropy in a particular way may differ [23]. Thus, one contribution of this paper is to demonstrate that the management of corporate philanthropy through foundations is a response to bottom-up initiatives, while channeling through donations is a response to a top-down strategy.

Thirdly, the work seeks to show that philanthropic actions that directly affect the community are practices that address or take into account the requirements of other stakeholders [18,33]. Most papers have focused on the effect that philanthropic actions have on a specific stakeholder [13], but there are no papers that analyze how all the main stakeholders affect a company's corporate philanthropy. We understand that the interests, requirements and demands of each stakeholder are different, and that the company must take them all into account in its management to determine the social value for the company. In this sense, this paper contributes to the literature by demonstrating that the management of philanthropic actions through foundations and donations relates to the requirements of the investors, employees and community.

A quantitative methodology is used to address these objectives. Specifically, an empirical analysis is performed using a binomial logit with respect to the management of corporate philanthropy channeled through foundations and, a regression analysis using Ordinary Least Squares (OLS) with respect to the management of philanthropy channeled through donations. The analysis of the proposed models is performed on a sample of 221 European companies indexed in the Dow Jones Sustainability Index in the year 2018.

The rest of the paper is organized as follows. Section 2 presents the literature review and hypotheses. In the third section, we present the data and the method of estimation. In Section 4, we analyze and discuss the results, show the main findings and, finally, we present our conclusions.

\section{Review of the Literature and Hypotheses}

A company's actions in the field of philanthropy are directly related to the community, which is its target, and indirectly to the rest of the stakeholders [34]. The stakeholders that the company considers in its management are consumers, employees, investors, the community, and suppliers [16,32]. In relation to corporate philanthropy, the first four are affected by these practices [13]. Suppliers are not usually considered, as there is usually no demand from suppliers for companies to engage in philanthropic activities. It is usually the company that requires its suppliers to comply with certain norms and standards related primarily to human, labor and environmental rights.

If philanthropic actions constitute a mechanism through which the company can manage its relationship with certain key stakeholders-employees, clients and capital markets [35]—it is necessary to specify how these stakeholders affect the companies' philanthropic strategy. 


\subsection{Theoretical Framework}

Corporate philanthropy has been approached using different theoretical frameworks. Previous analysis has employed mainly agency theory, legitimacy theory and stakeholder theory. Our work aims to analyze whether corporate philanthropy is a strategy that a company uses to transmit attributes that are difficult to observe, such as its social commitment, to its main stakeholders [36]. In this sense, the theory of stakeholders [16] and, more specifically, signaling theory as theoretical frameworks are applicable [37,38].

Stakeholder theory is based on the basic premise that managers must manage business objectives by reconciling them with the demands and expectations of their stakeholders [16,39] in order to continue operating and achieving their objectives $[39,40]$. In this sense, the different pressures and expectations of stakeholders determine business behavior and, more specifically, should determine corporate philanthropy policies.

The theory of signaling completes the previous theoretical framework, suggesting that companies improve relations with their stakeholders by using different types of signals [37]. Thus, the entity (the sender) can take actions (corporate philanthropy) that indicate its ability to meet the needs of stakeholders $[37,38,41]$, so that they are observable by external agents (receivers-in our case, the stakeholders, who interpret the signal) $[37,41,42]$. Stakeholders interpret these signals by capturing the intentionality and behavior of the transmitter, which can generate positive perceptions regarding the entity if they consider the signal reliable, or negative ones if unreliable $[43,44]$.

In the 1990s, this theory began to be applied to business ethics [45], and later was applied in the field of CSR, within which 'corporate philanthropy' refers to the practices that a company carries out to generate positive perceptions and attitudes in some stakeholders [37,44].

The theory of signaling explains the reaction of different receptors under conditions of imperfect information $[38,46]$. Different practices of social responsibility may convey different messages, so they need to be analyzed separately [46]. In this sense, the different ways of managing corporate philanthropy, whether through donations or foundations, could be signals issued by the company that generate different responses from the main stakeholders, since each form of management can be interpreted and perceived differently by stakeholders [23].

\subsection{Corporate Philanthropy as a Signal to the Community}

Corporate philanthropy is action taken to improve the well-being of the community or solve social problems [13]. A company adopts corporate philanthropy for different reasons [13], such as to strengthen ties with the community [3,4], repay in some way the resources that society has provided it or respond to external pressures [47] or community requirements [48,49]. This action can have a positive effect on society's disposition towards the entity [50].

Companies that actively interact with the public become an essential part of the community. These actions can contribute to the community's positive attitude towards the company, which seeks to improve the harmony between it and the community [50]. Companies can use their corporate philanthropy activities as signs of community engagement. Recent studies, however, show that the community does not perceive different categories of social contributions the same way [51]. The effectiveness of the signal in the community is largely determined by the visibility of the social practices and the cost to or monetary commitment by the company [51]. The fact that the company channels its philanthropic actions through a foundation gives them greater visibility and a more professional image. In addition, the implementation of these practices implies the long-term commitment of resources, stability in contributions, and commitment of a greater volume of corporate resources, not only monetary ones [28,29,52]. This way of management improves the effectiveness of the signal and helps cultivate a positive and socially responsible image of the company, decreasing the potential for community discontent and generating a positive climate for them [53].

Companies that channel their philanthropic actions through foundations are motivated by their desire to generate positive perceptions in the community. According to the theory of signaling, 
foundations are philanthropic practices that the company undertakes to signal its social commitment to the community. On the other hand, donations are not effective signals, in the sense that their professionalism is not perceived, they could be considered random or discretionary and, therefore, they do not meet the expectations of the stakeholders. It is possible that the entity's channeling of its social commitments through donations is not a measure that responds to community initiatives. In this sense, we propose the following hypotheses:

H1. There is a positive relationship between the management of corporate philanthropy through foundations and the community's attitude towards the company.

H2. There is a negative relationship between the management of corporate philanthropy through donations and the community's attitude towards the company.

\subsection{Corporate Philanthropy as a Signal to Employees}

Employees as a group are considered a main stakeholder, and their appreciation of corporate philanthropy is very important [54], even if such philanthropy does not bring them direct benefits. A positive relationship has been discussed between corporate philanthropy and employee cohesion [55], identification with the firm [56,57] and organizational commitment [58]. The firm's social commitments can respond to the demand for moral and ethical attitudes by employees [59] and provide them with a perception of security, affiliation and esteem, reducing conflict and improving the work climate $[14,60]$.

Entities rely on their employees [61,62] and, to this end, develop, among other strategies, a corporate philanthropy that creates positive attitudes among employees towards the company, such as pride in belonging or in cohesion and unity [55].

Based on the theory of signaling, the company might take into account the employees' attitudes, impulses and motivations when proposing its corporate philanthropy. Firstly, the company wants to send a signal that communicates its values and that the company is a good corporate citizen [61-63], in accordance with the demands and interests of its employees [63,64]. Employees interpret these signals and develop resulting attitudes towards the company $[62,64]$. This raises the question of whether how corporate philanthropy is managed through direct donations or foundations is an attempt to respond to employee initiatives and attitudes.

On the one hand, companies that develop their corporate philanthropy through foundations can create a climate of trust for their current or potential employees [19], tend to be more stable employers and increase employee tenure [65]. In this sense, the management of philanthropy through foundations could be used as a signal to employees. Donations, on the other hand, are often linked to management preferences and are often sporadic and discretionary: donations sometimes do not generate trust from employees $[64,66,67]$. In this regard, we propose the following hypotheses:

H3. There is a positive relationship between the management of corporate philanthropy through foundations and employees' attitudes towards the company.

H4. There is a negative relationship between the management of corporate philanthropy through donations and employees' attitudes towards the company.

\subsection{Corporate Philanthropy as a Signal to Customers}

Customers are another main stakeholder of the company. Today, clients are better organized, with more information and education, and, therefore, with greater demands on and requirements for companies, including those related to philanthropy [68]. Clients influence the decisions of entities through their control and sanction function [69]. Philanthropic activities may create and foster a belief in customers-that the organization adheres to high ethical standards and cares for the well-being of society [70], improving the assessment of corporate reputation [68,71], which may have a direct effect 
on customers' attitudes towards a company, their perceptions of the company and their purchasing behavior $[13,70]$.

The relationship between corporate philanthropy and customers, however, is not simple. Many companies use philanthropy as a marketing tool $[25,26]$, so if clients have bad experiences, or if their promises do not match reality [27,72], they are wary of the company's philanthropic actions [73,74]. In this sense, although clients demand certain ethical attitudes from companies and involvement in issues that go beyond the business activity itself, they would value negatively if these were done as marketing policies or policies to improve the business image [75]. In this context, the different ways of managing philanthropy (through direct donations or through foundations) could be signs that communicate a more altruistic or fundamental nature of these actions to customers [76].

Managing corporate philanthropy through foundations often involves the transfer of not only monetary resources but also time, service and variety of causes served, which are valued highly and perceived well by the customer $[31,76]$. In addition, companies tend to designate a greater amount of resources [28], which is also perceived favorably by customers [77].

On the other hand, cash donations are often linked to the personal preferences of management, which seems to have a negative effect on customers' attitudes towards the company [75] or be perceived by customers as less moral [76].

Channeling corporate philanthropy through foundations could be a company's response to building customer confidence. Cash, sporadic or discretionary donations may not be a response to customer demands. The following assumptions are made in this regard:

H5. There is a positive relationship between the management of corporate philanthropy through foundations and customers' attitudes towards the company.

H6. There is a negative relationship between the management of corporate philanthropy through donations and customers' attitudes towards the company.

\subsection{Corporate Philanthropy as a Signal to the Capital Market}

Investor expectations are also relevant for a company when it comes to planning its corporate philanthropy [78]. Investors may perceive that companies which actively engage in philanthropy tend to be more concerned with investor interests, providing more transparent information and avoiding misconduct [79] or agency issues [80]. In addition, a number of institutional investors are demanding action in the area of CSR [81]. This trend has been increasing in recent years, with many investors establishing ethical criteria for investment selection [82]. Thus, factors like the capital structure or the existence of institutional owners may influence the corporate philanthropy policy that companies follow $[29,82]$. Companies may perceive that investors are encouraging, increasing pressure on them and valuing their engagement in philanthropic activities [58]. How corporate philanthropy is managed may be determined by investor perceptions of social performance. The management of corporate philanthropy through foundations implies a more stable and specialized social policy that is more easily integrated into the rest of the company's strategies [28], which can also be more easily evaluated by investors. By channeling corporate philanthropy through organizations independent of management, a company's actions are more transparent, reducing information asymmetries [23,83]. For their part, donations are more linked than foundations to management preference, and more discretionary, so they could be perceived by investors as unreliable. In this sense, better investor perceptions or attitudes towards the company would require it to manage corporate philanthropy through foundations $[29,84]$. To the extent that companies have a higher market value, investors may be more demanding in terms of planning and managing resources for philanthropy and may require that they be managed through foundations in the interest of transparency and professionalism. In this regard, the following scenarios are proposed: 
H7. There is a positive relationship between the management of corporate philanthropy through foundations and the capital market valuation.

H8. There is a negative relationship between the management of corporate philanthropy through donations and the capital market valuation.

\section{Data and Method of Estimation}

\subsection{Sample}

This study focuses on 221 European companies in 13 countries in 2018. For the data related to the existence of a foundation, the amount of donations, the degree of alignment between companies and stakeholders (controversies with community, employees and clients) for the market value, as well as quality of the information disclosed, we used the Sustainalytics database, a data provider for socially responsible investors. This database creates a profile of each company based on surveys and information obtained from the companies' websites, carried out by experts.

This database has been used in previous research [9,19], and provides CSR data for the DJSI STOXX indexes to assess sustainability performance, taking into consideration the Key Performance Indicators for ESG 3.0 developed by DVFA (Deutsche Vereinigung fur Finanzanalyse und Asset Management) and EFFAS (The European Federation of Financial Analysts Societies). This database provides indices for each measured variable. The variables are qualified by experts considering the data available in the information disclosed in reports and websites, as well as information obtained from interviews with managers. The validity and reliability of these measures is ensured by following external principles or standards as a reference and by applying a systematic and pre-established methodology to determine a company's sustainability score [85].

For our study, we used, as dependent variables, the variables related to the management of corporate philanthropy-the existence or not of foundations and the percentage of money destined to direct donations. As independent variables, we used the controversial event indicators in this database. In addition, the quality of the information disclosed by the company is introduced as a control variable. The reports disclosed serve as a tool for stakeholders to evaluate companies' philanthropy and are essential for managing strategy and stakeholder relations $[86,87]$. Another element to monitor is the sector in which the company operates [29]. Thus, in general, the industries with the greatest effect on stakeholders tend to make greater efforts in their social policies. Therefore, social practices differ by sector [88] and must be controlled for. Finally, we include as a control variable the country to which each company belongs, classifying them according to the geographical area where they are located. Thus, we take into account that different cultures, economic and political ideologies, conceptions of social welfare and legal systems coexist in Europe, any of which could generate heterogeneous perceptions of social responsibility activities and policies, and influence the philanthropic activities developed by the company [88].

\subsection{Measures and Method of Estimation}

In accordance with the objectives of the study, the following logistic and linear regression models are proposed:

$$
\begin{aligned}
\text { Foundation }= & \beta \mathrm{o}+\beta 1 \text { ControvCommunity }+\beta 2 \text { ControvEmployees } \\
& +\beta 3 \text { ControvCustomers }+\beta 4 \text { Market }+\beta 5 \text { CSRReport } \\
& +\beta 6 \text { Industry }+\beta 7 \text { British Isles } \\
& +\beta \text { Continental countries }+\beta 9 \text { Northen countries } \\
\text { Donations }= & \beta \mathrm{o}+\beta 1 \text { ControvCommunity }+\beta 2 \text { ControvEmployees } \\
& +\beta 3 \text { ControvCustomers }+\beta 4 \text { Market }+\beta 5 \text { CSR Report } \\
& +\beta 6 \text { Industry }+\beta 7 \text { British Isles } \\
& +\beta \text { Continental countries }+\beta 9 \text { Northen countries }
\end{aligned}
$$


The "foundation" is a dichotomous variable that takes the value of 1 when the company manages its corporate philanthropy through a foundation and 0 otherwise $[23,29]$. The "donations" variable is measured as the percentage of net profit allocated to donations $[9,79]$. The degree of alignment of each stakeholder with the company is measured through the number of controversies and incidents that occur between each stakeholder and the firm. They are evaluated by taking into account, among other things, the following: the frequency and/or pattern of such controversies, the seriousness of the case, the company personnel involved and their seniority. Variables on stakeholder controversies are rated on a scale from 0 to 5 depending on the risk to the company's reputation and the potential social and environmental impact. Controversies and incidents have values between 0 , when there is no evidence of controversy in any of the indicators that define the variable. Category 1 reflects controversies or incidents that have a low impact and negligible risk for the company. Category 2 includes those controversies or incidents with stakeholders that have a moderate social impact but pose a minimal risk to the company. Category 3 includes controversies or incidents that have a significant social impact and risk. Category 4 expresses that controversies have a high social impact and a high risk for the business. Finally, category 5 includes controversies with severe social impact and high risk for the company. The lower the number of incidents and controversies, the more alignment each stakeholder group will have with the company [19].

"Controversies with the community" identifies incidents or social controversies, using as indicators conflicts and incidents with the local community, as well as incidents related to human rights or collaboration with repressive regimes. "Controversies with employees" identifies incidents with employees. The indicators used are injuries, occupational diseases, days lost due to absenteeism, number of deaths, strikes and lockouts, and human rights complaints. "Controversies with customers" are measured in relation to complaints about product quality and safety, effectiveness of response channels, data protection and the accuracy of advertising. Finally, the "Market value" variable is measured by the logarithm of the market capitalization value. In relation to the control variables, the "Quality of the CSR report" takes a value of 0 if the entity does not publish a CSR report, 0.25 if it is published, and values of $0.50,0.75$ and 1 according to the quality levels established by the GRI [89]. The highest value is linked to the assurance of the sustainability report $[89,90]$. The "sector" takes values between 1 and 5 depending on its effect on stakeholders, establishing groups following the FTSE4good classification, and distinguishing between sectors with high, medium-high, medium-low and low impact [91]. Finally, the geographical area is included as a control variable. The geographical area is classified into four European regions that present homogeneity in relation to their corporate social responsibility policies: the British Isles, Northern Europe, Continental Europe and the Mediterranean [88,92].

\section{Results and Discussion}

Table 1 shows the descriptive statistics and the correlations between the variables, and Table 2 shows the results of the logistic and OLS regression. 
Table 1. Descriptive statistics and correlations.

\begin{tabular}{|c|c|c|c|c|c|c|c|c|c|c|c|c|c|c|}
\hline $\mathrm{N}^{0}$ & Variables & Mean & SD & 1 & 2 & 3 & 4 & 5 & 6 & 7 & 8 & 9 & 10 & 11 \\
\hline 1 & Foundation & 0.498 & 0.501 & 1 & & & & & & & & & & \\
\hline 2 & Donation & 0.527 & 0.401 & $0.268^{* *}$ & 1 & & & & & & & & & \\
\hline 3 & Controv. Community & 3.154 & 1.004 & $-0.207^{* *}$ & 0.054 & 1 & & & & & & & & \\
\hline 4 & Controv. employees & 4.437 & 1.205 & $-0.319^{* *}$ & -0.001 & $0.151 *$ & 1 & & & & & & & \\
\hline 5 & Controv. Customers & 3.195 & 1.265 & -0.112 & 0.000 & $0.226^{* *}$ & 0.171 * & 1 & & & & & & \\
\hline 6 & Market & 4.044 & 0.584 & $0.367^{* *}$ & 0.067 & $-0.182 * *$ & $-0.293 * *$ & -0.144 * & 1 & & & & & \\
\hline 7 & CSR Report & 0.571 & 0.375 & $0.249^{* *}$ & 0.124 & -0.019 & $-0.181^{* *}$ & -0.154 * & $0.254^{* *}$ & 1 & & & & \\
\hline 8 & Industry & 3.371 & 1.595 & -0.027 & -0.008 & 0.006 & $-0.148^{*}$ & $-0.502 * *$ & 0.040 & $0.137^{*}$ & 1 & & & \\
\hline 9 & British Isles & 0.270 & 0.446 & $-0.180^{* *}$ & $0.141 *$ & 0.014 & 0.069 & -0.067 & 0.077 & $-0.303 * *$ & -0.027 & 1 & & \\
\hline 10 & Continental countries & 0.310 & 0.464 & $0.208^{* *}$ & -0.100 & $-0.146 *$ & $-0.242 * *$ & -0.048 & $0.217^{* *}$ & 0.071 & -0.16 & $-0.411 *$ & 1 & \\
\hline 11 & Northern countries & 0.260 & 0.441 & $-0.162 *$ & $-0.184 * *$ & 0.042 & $0.156^{*}$ & 0.119 & $-0.146^{*}$ & -0.017 & -0.35 & $-0.364^{* *}$ & $-0.402 * *$ & 1 \\
\hline
\end{tabular}

* Significance at $p<0.05 .{ }^{*}$ Significance at $p<0.001$. 
Table 2. Regression models.

\begin{tabular}{ccc}
\hline & Logit Values & OLS Values \\
\hline Variable & Foundations & Donations \\
\hline Constant & $-1.060(1.812)$ & $0.232(0.301)$ \\
Controv. Community & $-0.333^{*}(0.179)$ & $0.016(0.028)$ \\
Controv. Employees & $-0.468^{* * *}(0.157)$ & $0.005(0.024)$ \\
Controv. Customers & $-0.249(0.181)$ & $0.002(0.028)$ \\
Market & $1.477^{* * *}(0.349)$ & $0.049(0.053)$ \\
CSR Report & $0.471(0.497)$ & $0.144(0.085)^{*}$ \\
Industry & $-0.238^{* *}(0.130)$ & $-0.007(0.020)$ \\
British Isles & $-2.228^{* * *}(0.627)$ & $-0.028(0.097)$ \\
Continental Countries & $-1.153^{* *}(0.572)$ & $-0.206(0.090) * *$ \\
Northern Countries & $-1.621^{* * *}(0.568)$ & $-0.241(0.091)^{* * *}$ \\
\hline$R^{2}$ & - & 0.100 \\
Pseudo R & 0.249 & - \\
Root MSE & - & 0.392 \\
Probability $>X^{2}$ & 0.000 & - \\
\hline
\end{tabular}

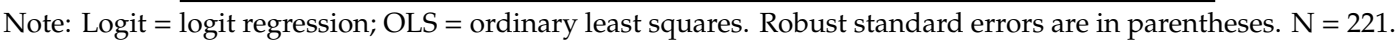

* Significance at $p<0.1$. ${ }^{* *}$ Significance at $p<0.05$. ${ }^{* * *}$ Significance at $p<0.001$.

Analysis of the averages shows that half of the companies channel their corporate philanthropy through foundations. Half of the companies in the sample make direct donations. There are different levels of incidents and controversies with the various stakeholders, with the highest being related to employees and the lowest being related to the community.

In relation to correlations, we observe that foundations are associated with lower levels of community- and work-related controversies and incidents. It appears that a greater degree of alignment between the community and the company encourages the latter to manage its corporate philanthropy through foundations [34,48,49], improving the climate of relations between the two [4,39]. Through foundations, links are established with the community and its demands are managed in order to favor and strengthen existing relations $[3,4,34,50]$.

Employees, in turn, constitute an influential group among the stakeholders [55], and drive, among other strategies, how corporate philanthropy is managed [55]. The existence of a lower number of controversies, and therefore, a greater identification of employees with the entity, leads them to demand planned moral and ethical attitudes from companies [59]. There is a positive relationship between corporate philanthropy managed through foundations and company cohesion with employees [58-60]. Channeling philanthropy through foundations ensures that it is not occasional or superficial and builds trust [67]. The results show that companies consider their employees when establishing their corporate philanthropy [61,62].

There is no significant relationship, however, between the existence of foundations and the volume of controversies and incidents with customers. This may be because customers are not the primary target audience when it comes to establishing a corporate philanthropy strategy [78], because the social commitment that clients value differs from the commitment that is developed through foundations $[92,93]$ or even because they consider these actions a marketing tool [72,74]. The results show that corporate philanthropy is not related to customers' attitudes.

The capital market has a positive and significant relationship with the existence of foundations. Investors may perceive that this type of action benefits them because of the better climate it creates [94,95], the greater transparency [79] and the reduction in agency problems [29,84] or because it is demanded by certain investors $[29,79,81]$. On the other hand, correlations show that incidents and controversies with various stakeholders are negatively associated with the market value of the company [96]. Companies are less valued by the market when there are incidents with their stakeholders. 
Donations, however, are not related to the attitudes of the main stakeholders towards the company. It is clear that these are policies carried out at the discretion of the company without being integrated into the business strategy aimed at the stakeholders. Firstly, although donations are actions directed to the community, they are not associated with the greatest harmony with this stakeholder. The results show that the effectiveness of these practices is not related to economic value, but possibly to social value [10], which requires visibility of collaborative actions [51]. Second, correlations do not show relationships between donations and improved employee attitudes. Cash donations are not sufficient to reflect the social justice developed by the company and therefore, do not affect the commitment and involvement of employees [19,58]. Third, we also found no significant correlation between corporate philanthropy and improved consumer attitudes toward the company. Consumers are skeptical of philanthropic practices that involve only one cash transaction. Finally, no significant relationship is found between donations and investor response. The capital market can understand these practices as management's liberality. In short, cash donations as such do not appear to affect the company's relationship with its major stakeholders. This practice, however, is influenced by the disclosure of social information and the culture of the country.

On the other hand, there are significant correlations between the level of incidents and controversies between different stakeholders, which indicates that when an organization has incidents with a given stakeholder, conflicts with others are likely to occur. A conflict situation worsens the work climate, which affects customer relations [33,97] and possibly, financial performance as well [98]. Incident and controversy management must be addressed with other stakeholders in mind, as there are interrelations between stakeholders and between stakeholders and companies [18]. Overall, the results of our study suggest that corporate philanthropy channeled through foundations follows a strategic stakeholder-driven approach. By contrast, donations are actions that are not part of the business strategy aimed at stakeholders and are possibly more linked to management preferences. When companies have lower levels of incidence, and therefore, better relations with stakeholders, they tend to formalize their corporate philanthropy through foundations, which can be considered to indicate social performance, and of the firm's orientation towards stakeholders or to take into account bottom-up initiatives. Strategies that do not directly target employees or investors are seen to affect their performance [24]. There is, thus, a convergence of shareholder, employee and community interests, an indicator that corporate philanthropy is being strategically managed [24]. Donations, however, do not appear to be a reliable signal to stakeholders [27].

We also observed that the quality of the reports is positively and significantly related to the existence of foundations and donations, showing that there is a relationship between corporate philanthropy and its different modes of management [99]. In addition, the quality of a company's CSR reports is related to employees, customers and markets, showing that it is a source of relevant information for them. The quality of the reports is also associated with the sector and the country in which the company operates. These results are reinforced in the regression analysis shown in Table 2 , where a logit regression is applied when the dependent variable is foundations, and an OLS regression when the dependent variable is donations.

Like the results obtained in the correlations, the regression analysis shows that there is a significant inverse relationship between the level of controversies and incidents with the community and the existence of foundations. We can conclude that the community demands this type of practice from the company because of the greater transparency on the destination of resources, and the recognition of the support of social causes [31]. Their greater visibility makes them effective signals to communicate the company's social commitment [51]. The decision to channel corporate philanthropy through donations, however, is not associated with the community. On the contrary, monetary donations provide an image of less stability in the company's commitment to social causes and are not associated with the demands of the community. The ability of donations as a signal to communicate the company's social commitment is not effective. Thus, hypotheses 1 is accepted, while hypothesis 2 is rejected. 
With respect to employees, the empirical analysis shows an inverse relationship between employee conflict and the existence of foundations, while the relationship between employees and donations is not significant. The results support hypothesis 3, but hypothesis 4 is rejected. The greater harmony and collaborative spirit of the employees is associated with the existence of foundations that imply a greater social commitment, as they are more durable practices and coherent with the social values of the company [14,19]. Thus, foundations would be a signal of the integration of social values in the company rather than practices associated with morality or management discretion $[64,66,67]$. On the other hand, as Block et al. point out [61], employees do not seem to demand social practices that only involve the transfer of resources [19,41]. With regard to customers, however, neither foundations nor donations are related to the attitudes of customers towards the company, and therefore, hypotheses 5 and 6 are rejected, as no significant relationship can be found. Thus, neither foundations nor donations are reliable signals for customers [100]. Donations may be perceived by clients as unethical management practices [69]. Clients may view foundations as marketing actions by the company to counteract negligent or controversial behavior [49]. Other mechanisms would be necessary to reduce the level of skepticism of the consumer $[25,26]$.

Market value is also associated with the management of corporate philanthropy through foundations, showing that financial performance reinforces social performance [101]. The results show that foundations could be a good vehicle for communicating the social commitment or creation of social value of companies [36], and be perceived by investors as a signal of long-term sustainability [9]. Donations, however, do not seem to be established to meet the demands of investors, but they may respond to managers' interests. This leads us to accept hypothesis 7 and reject hypothesis 8 . Foundations are attentive to the valuation that investors make of the company, but donations could be perceived by investors as an agency problem in which management does not consider the interests of owners or investors $[9,15]$.

Philanthropy through foundations tries to respond to community, employee and investors' initiatives. In this sense, corporate philanthropy is part of a company's social strategy aimed at meeting the social expectations of these three groups. Corporate philanthropy integrated into the core business would lead companies to respond to the direct demands of the community and indirect demands from other stakeholders, such as employees and investors. Pressure or the desire to take into account the stakeholders leads companies to manage their philanthropy through foundations [45]. The development of a corporate social strategy involves focusing on improving relations with stakeholders [97], which is not the case with donations. The findings show that decision-making on social engagement must address the demands of stakeholders and consider their perceptions. Thus, the study reflects philanthropy as a communication tool that improves the company's relationships with some of its key stakeholders. The different practices act as signals that inform the level of social commitment of the company. In this way, some practices can be perceived by the stakeholders as a signal of social responsibility, orientation of the business to the public interest and integration of social values in the company. Other practices, on the contrary, could be perceived as discretionary practices linked to the improvement of the business image and to the moral or instrumental interests of the management. In this sense, corporate philanthropy channeled through foundations would serve the company to communicate its social commitment to some of its key stakeholders- community, employees and investors-while donations alone do not seem to be sufficient to generate positive perceptions in these groups. Finally, it can be seen that the management of corporate philanthropy through foundations depends on the sector to which the company belongs. The country also proves to be a significant variable, indicating that channeling philanthropic actions through foundations and donations also responds to a cultural issue and that, depending on the country, there is a preference for a particular strategy $[102,103]$. 


\section{Conclusions}

Companies channel their philanthropic strategy through foundations in response to the pressures and initiatives of various stakeholders [48,49]. Foundations are part of the social strategy, managing its possible effects or reactions not only of the directly affected stakeholders-the community-but also taking into account its indirect effects on others. Through its social action, it can be seen that the company's management of its corporate philanthropy through foundations is perceived as a reliable and transparent signal by most of the main stakeholders, and responds to the desire to take into account their initiatives. In short, foundations form part of the company's social strategy, which seeks to strengthen ties with stakeholders and respond professionally to their demands and initiatives [4]. Likewise, the high value that investors place on the management of social resources through foundations may be a response to the fact that managing philanthropy through foundations clarifies the firms' decision-making.

Donations do not take stakeholders' attitudes into account [27]. Companies that manage their philanthropy solely through donations do not try to meet the expectations of the various stakeholders analyzed. In addition, donations, to the extent that they are not related to the market value of the company, may reflect an agency problem between owners and directors, and are not integrated into the company's business strategy [5]. Thus, one contribution of this study is to show how the management of corporate philanthropy differs in the case of foundations, where bottom-up initiatives are taken into account and the business strategy is aligned with stakeholders, from the case of donations, where the strategy is set up-down.

This study is a contribution to the theory of stakeholders, as it analyzes how companies manage corporate philanthropy to meet the demands of stakeholders, according to their perceptions. It also represents a contribution to the theory of signaling, insofar as the company channels resources in a way that is perceived as reliable by the stakeholders and generates trust. The results show that foundations could be a good vehicle for communicating the social commitment or creation of social value of companies [36] and be perceived by investors as a signal of long-term sustainability [9]. The fact that companies have a corporate philanthropy policy is not a sufficient condition for generating good relations with stakeholders; rather, it is necessary that practices address the demands and requirements of different groups. In this sense, the community demands planned and specialized social actions of certain relevance and public visibility. On the other hand, employees look for social actions that reflect that the company where they work integrates social values in the business strategy. Finally, investors must perceive that these practices are managed as part of the company's social performance that allows sustainability to be achieved. In this sense, foundations seem to be practices that seek to address such requirements.

However, the company's relationship with clients is not a determining factor in setting its corporate philanthropy strategy, so it seems that this is not designed to respond to the expectations of clients, nor does it seem that they are the target audience when the entity adopts this type of action [78]. Although no conclusive results have been obtained for clients, this cannot lead us to believe that this interest group is unimportant to companies, but rather that other strategies should be followed to meet their demands. Thus, the results show that the quality of the information disclosed is valued by customers. For this stakeholder group, communication is fundamental.

Another contribution of this study is to highlight that there is a relationship among the various stakeholders, so that an action aimed at one of them improves the relationship with the others [34]. These findings are particularly relevant in business management, which must take into account that different practices and ways of managing philanthropy act as signals that are perceived and valued differently by different stakeholders. Companies must choose their philanthropic practices by taking into account the expectations of the different groups and knowing the attitudes of the stakeholders towards each of them.

In relation to the above, the theory of signaling is applicable. Foundations and donations are signals perceived differently by stakeholders. On the one hand, foundations are perceived positively 
by the community, employees and investors. Foundations are organizations specialized in addressing certain social causes of public interest, and their actions are signals to stakeholders of the creation of social value. On the other hand, donations are considered, by the stakeholders analyzed, to be an unreliable signal of social commitment because they are practices that are more subject to the personal motivations of the management, carried out discretionally and in the short term, making it difficult for stakeholders to associate them with the integration of social values into the business strategy $[15,23]$. The fact that corporate philanthropy is channeled through foundations has been a trend in recent years. The reasons for this may vary, but the results obtained show that this strategy is perceived positively by the main stakeholders. In this sense, we can say that the actions are not an attempt to seek legitimacy from the stakeholders, but are rather driven and motivated by them. A better alignment of the stakeholders with the entity stimulates the existence of foundations.

Through foundations, companies manage their corporate philanthropy in an integrated and professional way, developing it in a planned manner and taking into account the demands of stakeholders and the effect of other policies, such as disclosure through quality reports. Donations, on the other hand, do not appear to be related to stakeholder initiatives. Finally, we must take into account that the sector and cultural characteristics of each country influence the decision of companies to manage their corporate philanthropy through either foundations or donations.

Nowadays, companies have to attend to a greater number of social and environmental requirements. Stakeholders demand a real social commitment. In this sense, the results show that corporate philanthropy cannot be a marketing tool at the service of management, but must be part of the business strategy in its commitment to create social value and to respond to the requirements of different stakeholders. In this way, corporate philanthropy is identified with practices to achieve the common good and ensure the long-term sustainability of the company. There is little empirical research that addresses this issue, so this study could serve as a basis for future studies on the effect of different stakeholders on social policy. Thus, future research could consider the role of stakeholders in the effectiveness of these practices and study the influence of some stakeholders on others and on business strategies.

Author Contributions: All authors wrote and read the paper, but their primary individual contributions were as follows: Section 1 is to be ascribed to M.V.L.-P. and R.G.-S. Section 2 is to be ascribed to M.L.A.-C. Section 3 is to be ascribed to M.L.A.-C. and S.R.-G., Sections 4 and 5 is to be ascribed to M.L.A.-C. and S.R.-G. All authors have read and agreed to the published version of the manuscript.

Funding: This research was funded by R\&D PROJECTS. EUROPEAN REGIONAL DEVELOPMENT FUND (ERDF) ANDALUSIA 2014-2020 OPERATIONAL PROGRAM, grant number B1-SEJ-387-UGR18.

Conflicts of Interest: The authors declare no conflict of interest.

\section{References}

1. Carroll, A.B.; Shabana, K.M. The business case for corporate social responsibility: A review of concepts, research and practice. Int. J. Manag. Rev. 2010, 1, 85-105. [CrossRef]

2. Hategan, C.D.; Sirghi, N.; Curea-Pitorac, R.I.; Hategan, V.P. Doing well or doing good: The relationship between corporate social responsibility and profit in Romanian companies. Sustainability 2018, 10, 1041. [CrossRef]

3. Al-Tabbaa, O.; Leach, D.; March, J. Collaboration between nonprofit and business sectors: A framework to guide strategy development for nonprofit organizations. VOLUNTAS Int. J. Vol. Nonpr. Organiz. 2014, 25, 657-678. [CrossRef]

4. Brammer, S.J.; Pavelin, S.; Porter, L.A. Corporate charitable giving, multinational companies and countries of concern. J. Manag. Stud. 2009, 46, 575-596. [CrossRef]

5. Deigh, L.; Farquhar, J.; Palazzo, M.; Siano, A. Corporate social responsibility: Engaging the community. Qual. Mark. Res. Int. J. 2016, 19, 225-240. [CrossRef]

6. Jamali, D. A stakeholder approach to corporate social responsibility: A fresh perspective into theory and practice. J. Bus. Ethics 2008, 82, 213-231. [CrossRef] 
7. Jamali, D.; Safieddine, A.M.; Rabbath, M. Corporate governance and corporate social responsibility synergies and interrelationships. Corp. Gov. Int. Rev. 2008, 16, 443-459. [CrossRef]

8. Seifert, B.; Morris, S.A.; Bartkus, B.R. Comparing big givers and small givers: Financial correlates of corporate philanthropy. J. Bus. Ethics 2003, 45, 195-211. [CrossRef]

9. Arco-Castro, L.; López-Pérez, M.V.; Pérez-López, M.C.; Rodríguez-Ariza, L. How market value relates to corporate philanthropy and its assurance. The moderating effect of the business sector. Bus. Ethics Eur. Rev. 2020, 29, 266-281. [CrossRef]

10. Porter, M.E.; Kramer, M.R. Creating shared value. Harv. Bus. Rev. 2011, 1, 5-18.

11. Elkington, J. Cannibals with Forks: The Triple Bottom Line of the 21st-Century Business; Capstone Publishing: Oxford, UK, 1997.

12. Felber, C.; Campos, V.; Sanchis, J.R. The common good balance sheet, an adequate tool to capture non-financials? Sustainability 2019, 11, 3791. [CrossRef]

13. Gautier, A.; Pache, A.C. Research on corporate philanthropy: A review and assessment. J. Bus. Ethics 2015, 126, 343-369. [CrossRef]

14. Grubor, A.; Berber, N.; Aleksić, M.; Bjekić, R. The influence of corporate social responsibility on organizational performances: A research in AP Vojvodina. Anal. Ekon. Fak. Subotici 2020, 56, 3-13. [CrossRef]

15. Barnea, A.; Rubin, A. Corporate social responsibility as a conflict between shareholders. J. Bus. Ethics 2010, 97, 71-86. [CrossRef]

16. Freeman, R.E. Strategic management: Strategic management: A stakeholder approach. The politics of stakeholder theory: Some future directions. J. Bus. Ethics 1984, 4, 409-421. [CrossRef]

17. Brammer, S.; Millington, A.; Pavelin, S. Is philanthropy strategic? An analysis of the management of charitable giving in large UK companies. Bus. Ethics Eur. Rev. 2006, 15, 234-245. [CrossRef]

18. Fassin, Y. Stakeholder management, reciprocity and stakeholder responsibility. J. Bus. Ethics 2012, 109, 83-96. [CrossRef]

19. Arco-Castro, L.; López-Pérez, M.V.; Pérez-López, M.C.; Rodríguez-Ariza, L. Corporate philanthropy and employee engagement. Rev. Manag. Sci. 2020, 14, 705-725. [CrossRef]

20. Leisinger, K.M. Corporate philanthropy: The "top of the pyramid". Bus. Soc. Rev. 2007, 112, 315-342. [CrossRef]

21. Smith, C. The new corporate philanthropy. Harv. Bus. Rev. 1994, 72, 105-114.

22. Petrovits, C.M. Corporate-sponsored foundations and earnings management. J. Account. Econ. 2006, 41, 335-362. [CrossRef]

23. Liang, H.; Renneboog, L. Corporate donations and shareholder value. Oxf. Rev. Econom. Policy 2017, 33, 278-316. [CrossRef]

24. Porter, M.E.; Kramer, M.R. The competitive advantage of corporate philanthropy. Harv. Bus. Rev. 2002, 80, 56-68. [PubMed]

25. Jin, L.; He, Y. How the frequency and amount of corporate donations affect consumer perception and behavioral responses. J. Acad. Mark. Sci. 2018, 46, 1072-1088. [CrossRef]

26. Xueying, T.; Lan, S. Impact of charitable donations of green food nutrition enterprise on consumers' purchasing decisions. Arch. Latinoam. Nutr. 2019, 69, 217-231.

27. Chen, J.C.; Patten, D.M.; Roberts, R.W. Corporate charitable contributions: A corporate social performance or legitimacy strategy? J. Bus. Ethics 2008, 82, 131-144. [CrossRef]

28. Marquis, C.; Lee, M. Who is governing whom? Executives, governance, and the structure of generosity in large US firms. Strat. Manag. J. 2013, 34, 483-497. [CrossRef]

29. Brown, W.O.; Helland, E.; Smith, J.K. Corporate philanthropic practices. J. Corp. Financ. 2006, 12, 855-877. [CrossRef]

30. Peterson, D.K.; Su, Y. Relationship between corporate foundation giving and the economic cycle for consumer-and industrial-oriented firms. Bus. Soc. 2017, 56, 1169-1194. [CrossRef]

31. Westhues, M.; Einwiller, S. Corporate foundations: Their role for corporate social responsibility. Corp. Rep. Rev. 2006, 9, 144-153. [CrossRef]

32. Initiative-GRI, G.R. Guía para la elaboración de memorias de sostenibilidad. Princ. Conten. básicos. Ámsterdam (Países Bajos): G. R. I. 2013, 25. Available online: http://www.cyta.com.ar/biblioteca/bddoc/bdlibros/334_gri. pdf (accessed on 1 September 2020). 
33. Matev, D.; Assenova, M. Application of corporate social responsibility approach in Bulgaria to support sustainable tourism development. Clean Technol. Environ. Policy 2012, 14, 1065-1073. [CrossRef]

34. Liu, G.; Eng, T.-Y.; Ko, W.-W. Strategic direction of corporate community involvement. J. Bus. Ethics 2013, 115, 469-487. [CrossRef]

35. Humphrey, J.E.; Lee, D.D.; Shen, Y. Does it cost to be sustainable? J. Corp. Financ. 2012, 18, 626-639. [CrossRef]

36. Mitrovic, M. Strategic communication concept implemented through the corporate political activities-suggested strategy modeling. Strat. Manag. 2019, 24, 13-20. [CrossRef]

37. Connelly, B.L.; Certo, S.T.; Ireland, R.D.; Reutzel, C.R. Signaling theory: A review and assessment. J. Manag. 2011, 37, 39-67. [CrossRef]

38. Moratis, L. Signaling responsibility? Applying signaling theory to the ISO 26000 standard for social responsibility. Sustainability 2018, 10, 4172. [CrossRef]

39. Madsen, P.M.; Rodgers, Z.J. Looking good by doing good: The antecedents and consequences of stakeholder attention to corporate disaster relief. Strat. Manag. J. 2015, 36, 776-794. [CrossRef]

40. McKnight, B.; Linnenluecke, M.K. How firm responses to natural disasters strengthen community resilience: A stakeholder-based perspective. Organ. Environ. 2016, 29, 290-307. [CrossRef]

41. Haski-Leventhal, D.; Foot, C. The relationship between disclosure and household donations to nonprofit organizations in Australia. Nonpr. Vol. Sect. Quar. 2016, 45, 992-1012. [CrossRef]

42. Spence, M. Signaling in retrospect and the informational structure of markets. Am. Econ. Rev. 2002, 92, 434-459. [CrossRef]

43. Schaefer, S.D.; Terlutter, R.; Diehl, S. Talking about CSR matters: Employees' perception of and reaction to their company's CSR communication in four different CSR domains. Int. J. Advert. 2020, 39, 191-212. [CrossRef]

44. Zerbini, F. CSR initiatives as market signals: A review and research agenda. J. Bus. Ethics 2017, 146, 1-23. [CrossRef]

45. Fombrun, C.; Shanley, M. What's in a name? Reputation building and corporate strategy. Acad. Manag. J. 1990, 33, 233-258.

46. Luffarelli, J.; Awaysheh, A. The impact of indirect corporate social performance signals on firm value: Evidence from an event study. Corp. Soc. Responsib. Environ. Manag. 2018, 25, 295-310. [CrossRef]

47. Campbell, J.L. Why would corporations behave in socially responsible ways? An institutional theory of corporate social responsibility. Acad. Manag. Rev. 2007, 32, 946-967. [CrossRef]

48. Herman, R.D.; Renz, D.O. Advancing nonprofit organizational effectiveness research and theory: Nine theses. Nonprofit Manag. Lead. 2008, 18, 399-415. [CrossRef]

49. Pedrini, M.; Minciullo, M. Italian corporate foundations and the challenge of multiple stakeholder interests. Nonprofit. Manag. Lead. 2011, 22, 173-197. [CrossRef]

50. Wang, H.; Qian, C. Corporate philanthropy and corporate financial performance: The roles of stakeholder response and political access. Acad. Manag. J. 2011, 54, 1159-1181. [CrossRef]

51. Canh, N.T.; Liem, N.T.; Thu, P.A.; Khuong, N.V. The impact of innovation on the firm performance and corporate social responsibility of vietnamese manufacturing firms. Sustainability 2019, 11, 3666. [CrossRef]

52. Monfort, A.; Villagra, N. Corporate social responsability and corporate foundations in building responsible brands. Prof. Inform. (EPI) 2016, 25, 767-777.

53. Gan, A. The impact of public scrutiny on corporate philanthropy. J. Bus. Ethics 2006, 69, 217-236. [CrossRef]

54. Gao, Y.; Yang, H. Do employees support corporate philanthropy? Evidence from Chinese listed companies. Manag. Organ. Rev. 2016, 12, 747-768. [CrossRef]

55. Brammer, S.; Millington, A. Corporate reputation and philanthropy: An empirical analysis. J. Bus. Ethics 2005, 61, 29-44. [CrossRef]

56. Kim, H.R.; Lee, M.; Lee, H.T.; Kim, N.M. Corporate social responsibility and employee-company identification. J. Bus. Ethics 2010, 95, 557-569. [CrossRef]

57. Glavas, A.; Godwin, L. Is the perception of 'goodness' good enough? Exploring the relationship between perceived corporate social responsibility and employee organizational identification. J. Bus. Ethics 2013, 114, 15-27. [CrossRef]

58. Brammer, S.; Millington, A.; Rayton, B. The contribution of corporate social responsibility to organizational commitment. Int. J. Hum. Resour. Manag. 2007, 18, 1701-1719. [CrossRef] 
59. Farooq, M.; Farooq, O.; Jasimuddin, S.M. Employees response to corporate social responsibility: Exploring the role of employees' collectivist orientation. Eur. Manag. J. 2014, 32, 916-927. [CrossRef]

60. Tuzzolino, F.; Armandi, B.R. A need-hierarchy framework for assessing corporate social responsibility. Acad. Manag. Rev. 1981, 6, 21-28. [CrossRef]

61. Block, E.S.; Glavas, A.; Mannor, M.J.; Erskine, L. Business for good? An investigation into the strategies firms use to maximize the impact of financial corporate philanthropy on employee attitudes. J. Bus. Ethics 2017, 146, 167-183. [CrossRef]

62. Raub, S. When employees walk the company talk: The importance of employee involvement in corporate philanthropy. J. Hum. Resour. Manag. 2017, 56, 837-850. [CrossRef]

63. Rupp, D.E.; Ganapathi, J.; Aguilera, R.V.; Williams, C.A. Employee reactions to corporate social responsibility: An organizational justice framework. J. Organ. Behav. Int. J. Ind. Occup. Organ. Psychol. Behav. 2006, 27, 537-543. [CrossRef]

64. Ni, N.; Qian, C.; Crilly, D. The stakeholder enterprise: Caring for the community by attending to employees. Strat. Organiz. 2014, 12, 38-61. [CrossRef]

65. Børsting, C.; Thomsen, S. Foundation ownership, reputation, and labour. Oxf. Rev. Econom. Policy 2017, 33, 317-338. [CrossRef]

66. Crilly, D.; Zollo, M.; Hansen, M.T. Faking it or muddling through? Understanding decoupling in response to stakeholder pressures. Acad. Manag. J. 2012, 55, 1429-1448. [CrossRef]

67. Zheng, Q.; Luo, Y.; Maksimov, V. Achieving legitimacy through corporate social responsibility: The case of emerging economy firms. J. World Bus. 2015, 50, 389-403. [CrossRef]

68. Kiessling, T.; Isaksson, L.; Yasar, B. Market orientation and CSR: Performance implications. J. Bus. Ethics 2016, 137, 269-284. [CrossRef]

69. Christmann, P.; Taylor, G. Firm self-regulation through international certifiable standards: Determinants of symbolic versus substantive implementation. J. Int. Bus. Stud. 2006, 37, 863-878. [CrossRef]

70. Walker, M.; Kent, A. The roles of credibility and social consciousness in the corporate philanthropy-consumer behavior relationship. J. Bus. Ethics 2013, 116, 341-353. [CrossRef]

71. Park, J.; Lee, H.; Kim, C. Corporate social responsibilities, consumer trust and corporate reputation: South Korean consumers' perspectives. J. Bus. Res. 2014, 67, 295-302. [CrossRef]

72. Maignon, I.; Ferrell, O.C. Corporate social responsibility and marketing: An integrative framework. J. Acad. Mark. Sci. 2004, 32, 3-19. [CrossRef]

73. Lee, K.H.; Shin, D. Consumers' responses to CSR activities: The linkage between increased awareness and purchase intention. Public Relat. Rev. 2010, 36, 193-195. [CrossRef]

74. Sweetin, V.H.; Knowles, L.L.; Summey, J.H.; McQueen, K.S. Willingness to punish the corporate brand for corporate social irresponsibility. J. Bus. Res. 2013, 66, 1822-1830. [CrossRef]

75. Yin, C.Y.; Bi, N.; Yu, H.Y. Do CEOs' personal donations matter? The impact of the CEO's personal donations on consumers' attitudes toward his/her company in China. J. Bus. Res. 2019, 100, 184-195. [CrossRef]

76. Langan, R.; Kumar, A. Time versus money: The role of perceived effort in consumers' evaluation of corporate giving. J. Bus. Res. 2019, 99, 295-305. [CrossRef]

77. Folse, J.A.G.; Niedrich, R.W.; Grau, S.L. Cause-relating marketing: The effects of purchase quantity and firm donation amount on consumer inferences and participation intentions. J. Retail. 2010, 86, 295-309. [CrossRef]

78. Rego, A.; Pina e Cunha, M.; Polónia, D. Corporate sustainability: A view from the top. J. Bus. Ethics 2017, 143, 133-157. [CrossRef]

79. Qian, C.; Gao, X.; Tsang, A. Corporate philanthropy, ownership type, and financial transparency. J. Bus. Ethics 2015, 130, 851-867. [CrossRef]

80. Zolotoy, L.; O'Sullivan, D.; Klein, J. Character cues and contracting costs: The relationship between philanthropy and the cost of capital. J. Bus. Ethics 2019, 154, 497-515. [CrossRef]

81. Song, Y.; Gianiodis, P.T.; Li, Y. Institutional ownership and corporate philanthropic giving in an emerging economy. Manag. Organ. Rev. 2016, 12, 357-385. [CrossRef]

82. Maas, K.; Liket, K. Talk the walk: Measuring the impact of strategic philanthropy. J. Bus. Ethics 2011, 100, 445-464. [CrossRef]

83. Bereskin, F.L.; Campbell, T.L.; Hsu, P.H. Corporate philanthropy, research networks, and collaborative innovation. J. Financ. Manag. 2016, 45, 175-206. [CrossRef] 
84. Werbel, J.D.; Carter, S.M. The CEO's influence on corporate foundation giving. J. Bus. Ethics 2002, 40, 47-60. [CrossRef]

85. Li, F.; Polychronopoulos, A. What a difference an ESG ratings provider makes. Res. Affil. Publ. 2020. Available online: https://www.researchaffiliates.com/en_us/publications/articles/what-a-difference-an-esgratings-provider-makes.html (accessed on 1 September 2020).

86. O'Riordan, L.; Fairbrass, J. Managing CSR stakeholder engagement: A new conceptual framework. J. Bus. Ethics 2014, 125, 121-145. [CrossRef]

87. Burke, J.J.; Clark, C.E. The business case for integrated reporting. Insights from leading practitioners, regulators, and academics. Bus. Horiz. 2016, 59, 273-283. [CrossRef]

88. Maon, F.; Swaen, V.; Lindgreen, A. One vision, different paths: An investigation of corporate social responsibility initiatives in Europe. J. Bus. Ethics 2017, 143, 405-422. [CrossRef]

89. Integrated Reporting IIRC Integrated Reported, G.R.I. 2015. Available online: https://integratedreporting. org/news/iirc-integrated-report-2015/ (accessed on 1 September 2020).

90. Al-Shaer, H.; Zaman, M. Board gender diversity and sustainability reporting quality. J. Contemp. Account. Econ. 2016, 12, 210-222. [CrossRef]

91. Arminen, H.; Puumalainen, K.; Pätäri, S.; Fellnhofer, K. Corporate social performance: Inter-industry and international differences. J. Clean. Prod. 2018, 177, 426-437. [CrossRef]

92. Albareda, L.; Lozano, J.M.; Ysa, T. Public policies on corporate social responsibility: The role of governments in Europe. J. Bus. Ethics 2007, 74, 391-407. [CrossRef]

93. Bhattacharya, C.B.; Sen, S. Consumer-company identification: A framework for understanding consumers' relationships with companies. J. Mark. 2003, 67, 76-88. [CrossRef]

94. Ailawadi, K.L.; Neslin, S.A.; Luan, Y.J.; Taylor, G.A. Does retailer CSR enhance behavioral loyalty? A case for benefit segmentation. Int. J. Res. Mark. 2014, 31, 156-167. [CrossRef]

95. Chen, M.H.; Lin, C.P. Understanding corporate philanthropy in the hospitality industry. Int. J. Hosp. Manag. 2015, 48, 150-160. [CrossRef]

96. Choi, J.; Wang, H. Stakeholder relations and the persistence of corporate financial performance. Strat. Manag. J. 2009, 30, 895-907. [CrossRef]

97. Tuan, L.T. Emotional intelligence as the departure of the path to corporate governance. Corp. Gov. 2013, 13, 148-168. [CrossRef]

98. Lee, P.K.; Lau, K.W.; Cheng, T.C.E. Employee rights and financial performance. J. Bus. Res. 2013, 66, 1861-1869. [CrossRef]

99. Ballou, B.; Casey, R.J.; Grenier, J.H.; Heitger, D.L. Exploring the strategic integration of sustainability initiatives: Opportunities for accounting research. Account. Horiz. 2012, 26, 265-288. [CrossRef]

100. Schons, L.M.; Cadogan, J.; Tsakona, R. Should charity begin at home? An empirical investigation of consumers' responses to companies' varying geographic allocations of donation budgets. J. Bus. Ethics 2017, 144, 559-576. [CrossRef]

101. Tonello, M. The Business Case for Corporate Social Responsibility 2011. Available online: https: //corpgov.law.harvard.edu/2011/06/26/the-business-case-for-corporate-social-responsibility./ (accessed on 1 September 2020).

102. Du, S.; Bhattacharya, C.B.; Sen, S. Maximizing business returns to corporate social responsibility (CSR): The role of CSR communication. Int. J. Manag. Rev. 2010, 12, 8-19. [CrossRef]

103. Du Plessis, A. A conceptual framework for corporate social responsibility: Internal, external and beyond. IPM J. 1987, 5, 12-13.

(C) 2020 by the authors. Licensee MDPI, Basel, Switzerland. This article is an open access article distributed under the terms and conditions of the Creative Commons Attribution (CC BY) license (http://creativecommons.org/licenses/by/4.0/). 